\title{
How Far Can Tourism Go? Residents' Attitudes toward Tourism Development in Yogyakarta City, Indonesia
}

\author{
Mohamad Yusuf \\ Faculty of Cultural Science, Universitas Gadjah Mada, Indonesia
}

Received: $2018-10-28$

Accepted: 2020-07-12

\begin{abstract}
Keywords:
cultural tourism;

Residents' attitude;

tourism development;

irritation index;

sustainable tourism;

Yogyakarta
\end{abstract}

Correspondent email:

myusuf@ugm.ac.id

\begin{abstract}
In the last 10 years, tourism has been rapidly growing in Yogyakarta. Studies show that tourism development in Yogyakarta has led to irritated feelings among local residents. This study aims to measure residents' attitudes toward tourism development in Yogyakarta by using validated measurement properties with a scale that measures residents' attitudes toward sustainable tourism development (SUSTAS). The instrument was distributed to 1,687 local residents living in three main tourist destinations in Yogyakarta. Confirmatory factor analysis was conducted to measure the validity and internal reliability of each variable. Descriptive quantitative analysis was also conducted to investigate the level of agreement among residents to each variable. Findings support the seven dimensions in the SUS-TAS scale. Perceived social cost and community participation are the variables with the lowest level of agreement among the variables. Results also confirm underlying tourism development problems in Yogyakarta.
\end{abstract}

2020 by the authors. Licensee Indonesian Journal of Geography, Indonesia.

Thions of the Creative Commo

Attribution(CC BY NC) licensehttps://creativecommons.org/licenses/by-nc/4.0/.

\section{Introduction}

Several studies have confirmed that tourism supports other economic elements (Song et al., 2011; Latimer, 1985) because it can be an economic trigger in the industry and help generate wide and long-term economic transformation (Poudel et al., 2016; Rasoolimanesh et al., 2017; Mansfeld \& Winckler, 2008). Tourism can also contribute to the empowerment of local culture and to the revitalization of cultural identity and heritage. Architectural and historical sites are preserved and protected to attract tourists (Inskeep, 1991). In addition, tourism has social benefits, which include increasing civic pride and social cohesion (Voon \& Voon, 2012; Aitchison \& Evans, 2001) and stimulating cultural interest and understanding by hosting visitors (Simpson, 2003). Others indicate that cultures benefit from interaction with increases in self-esteem and opportunities for mutual learning (Brown, 1998; Smith, 2003; Pennington-Gray et al., 2005; Stronza \& Gordillo, 2008). When many people from different cultures interact with one another, mutual understanding among different communities and cultures is strengthened (Brayrley et al., 1990; Sterkens \& Yusuf, 2015).

Despite the positive contributions of tourism to people's lives, tourism may also bring about negative impacts (Jooa et al., 2019; Shepherd, 2002; Maccarrone-Eaglen, 2009). Tourism may contribute to gradual shifting in a society's values, beliefs, and cultural practices. Local people may become eager to change their lifestyle in dressing, eating, entertainment, and so forth after they interact with tourists. The cultural values belonging to the community may gradually change. Local people begin to perceive themselves as tourists and adopt different cultural values and want the same luxuries as tourists. Ap and Crompton (1998) argued that tourism is perceived to escalate changes in individual behaviors, family relationships, collective lifestyle, moral conduct, and community organizations (cf. Brunt \& Courtney, 1999). Tourism can divide people into those who have more power to manage a destination and those who have less power. Similarly, intense migration from different cultures of people can give rise to social problems in the area. Several studies have shown that in general, women are more positively affected by tourism than men. Tourism can contribute to additional work opportunities, amplified selfconfidence, enhanced education, and standards of living with high family income. However, other researchers argue that tourism can change family structures and values that contradict its goal (McCreedy et al., nd; Agonos et al., 2015).

Tourism has begun to irritate the people in Yogyakarta. For instance, residents experience water shortage, scarcity, and limited area for agriculture for the first time, as reported in the short documentary titled, "At the Back of The Hotels" (Azami, 2015). This film has become viral as the expression of massive protests to the government. In the film, locals represent water scarcity by conducting a ritual replacing water with sand, and they use sand for daily needs, including drinking and bathing. Locals protested in the past when they did not obtain clear responses from a hotel representative and the government due to water protection. In the demonstration, locals asked for the transparency of the water system of the hotel and the government regulation on water usage, but they failed to receive any response. The conflict exploded after the assumptions of locals led to the 
intensive development of the hotel that caused this problem. Empirical research by an Indonesian environmental geographer has reported that the increasing water consumption in Yogyakarta is not only caused by population growth but also by the massive development of tourism activities (Purnama, 2016; Yusuf et al., 2018). The increasing water consumption potentially threatens the groundwater water crisis by up to $50 \%$ in this area.

The discussions above have indicated two sides of tourism impacts: positive and negative. Evidently, local residents are the major actors of tourism development processes and are directly affected by the tourism industry. Therefore, this study aims to measure residents' attitudes toward tourism development in Yogyakarta, Indonesia. This study is important, particularly with regard to the goal of tourism, that is, to create a sustainable tourism industry to benefit as many actors as possible and to minimize the negative sides of tourism. Sustainable tourism development means a harmonious relationship among tourists, locals, and tourist places. Some research projects have identified that social conflicts over tourist destination management occur, which is closely related to the lack of local people participation and the dominance of investors gaining profits from the tourism industry. Passengers Exit Survey has reported that approximately 14 million foreign tourists visited Indonesia in 2019. This increasing number is also in line with the foreign exchange income from the tourism sector, from USD 9.1 billion in 2012 to USD 19.29 billion in 2019 (BPS, 2020). Tourism has contributed approximately $10 \%$ of Indonesia's GDP, which is the highest percentage among the ASEAN countries. In 2016, Indonesian tourism's GDP growth increased to $5.2 \%$ and can reach $10 \%$. This growth rate is higher than that of agriculture, automotive, manufacturing, and mining industries. Accordingly, USD 1 million in foreign tourism exchange can generate USD 1.7 million, or a contribution of $170 \%$ to tourism GDP, the highest contributor among other industries (Yusuf et al., 2018).

Consequently, tourism has become the third-largest contributor to the national income after gas and rubber. Its value leads to an increase of the level of state concern on developing tourism sectors by enacting certain regulations for the management of tourism industries.

Table 1. Main Foreign Exchange in Indonesia, Year 2014_2016

\begin{tabular}{|c|c|c|c|c|c|c|}
\hline \multirow[b]{2}{*}{ Rank } & \multicolumn{2}{|c|}{2014} & \multicolumn{2}{|c|}{2015} & \multicolumn{2}{|l|}{2016} \\
\hline & $\begin{array}{l}\text { Type of Com- } \\
\text { modity }\end{array}$ & (Million USD) & $\begin{array}{l}\text { Type of Commodi- } \\
\text { ty }\end{array}$ & (Million USD) & $\begin{array}{c}\text { Type of Commodi- } \\
\text { ty }\end{array}$ & $\begin{array}{l}\text { (Million } \\
\text { USD) }\end{array}$ \\
\hline 1 & Gas \& Oil & $30,318.80$ & Gas \& Oil & $18,552.10$ & Palm Oil & 15,965 \\
\hline 2 & Coal & $20,819.30$ & Coal & $15,943.00$ & Tourism & 13,568 \\
\hline 3 & Palm Oil & $17,464.90$ & Palm Oil & $15,385.20$ & Gas \& Oil & 13,105 \\
\hline 4 & Tourism & $11,166.13$ & Tourism & $12,225.89$ & Coal & 12,898 \\
\hline 5 & Apparel & $7,450.90$ & Apparel & $7,371.90$ & Apparel & 6,229 \\
\hline
\end{tabular}

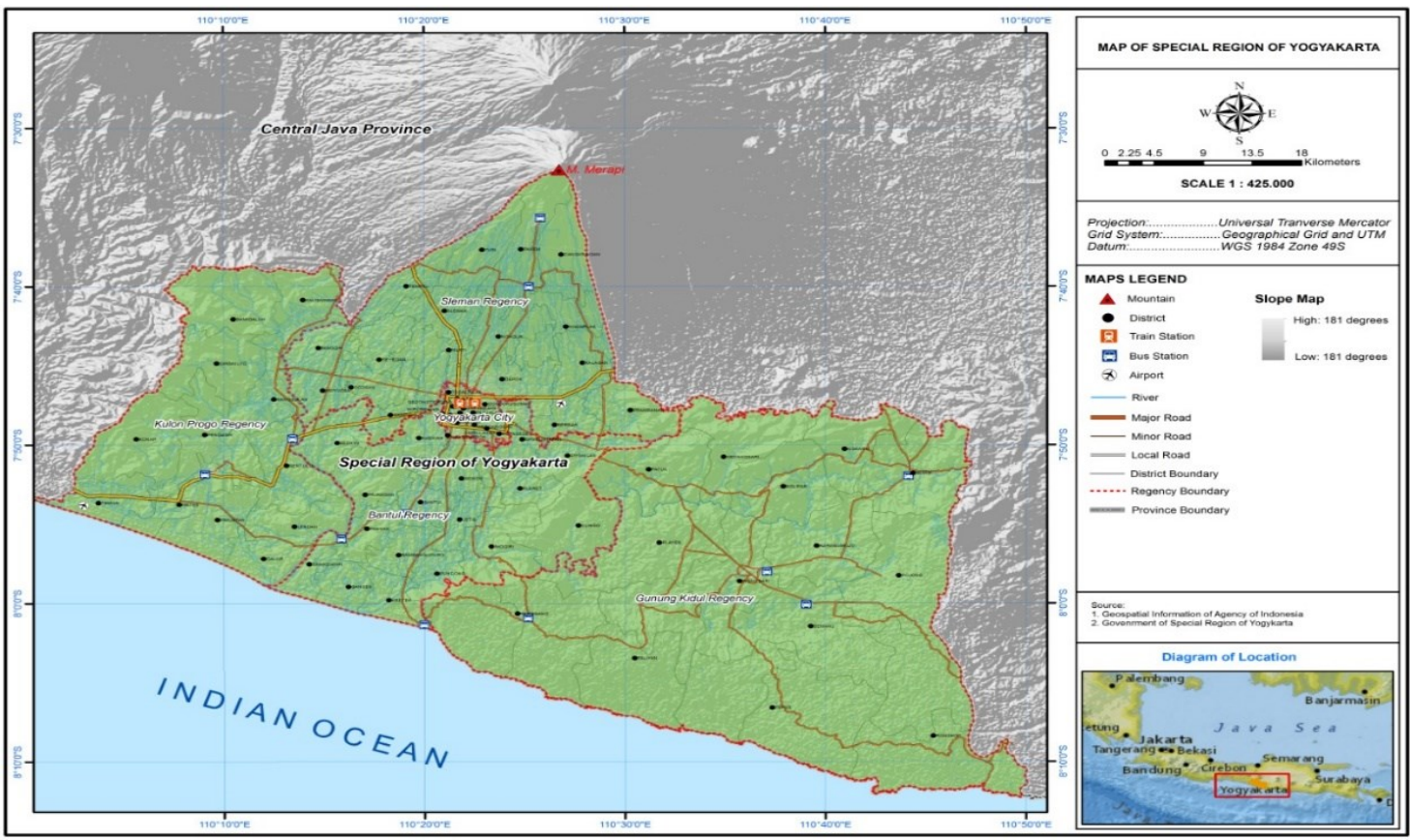

Figure 1. Map of Daerah Istimewa Yogyakarta Province 
This study focuses on tourism development in Yogyakarta. The city is one of the most well-known tourist destinations in Indonesia for natural and cultural tourism ${ }^{1}$. With regard to tourist visits, the data from the Central Bureau of Statistics (BPS) show that approximately four million tourists (domestic and international) visited the Special Region of Yogyakarta (DIY) in 2012, of which Yogyakarta is the capital, and the number increased to 4.8 million in 2017 (BPS, 2018). The number of tourists visiting DIY Province from 2015 to the present is reportedly greater than the population of Yogyakarta itself. The population of DIY in 2017 was 3,587,921. Meanwhile, Yogyakarta covers an area of $32.50 \mathrm{~km}^{2}$ with a total population of 417,744 in 2016.

For many people in Indonesia, particularly in Yogyakarta, the tourism sector is an important contributor to people's livelihood. Considering the significant contribution of tourism to businesses at the national and local levels, this research on residents' attitudes toward tourism development in Yogyakarta is profoundly important. Tourism can be a powerful economic engine that can benefit the people of Yogyakarta. If tourism is properly managed, then societal welfare can improve with the lowest possible environmental and social costs. However, if tourism is poorly developed, then the resource base used can collapse, and surrounding regions or even the entire country may suffer from consequences.

With the fast-growing tourism industry, people of Yogyakarta are concerned about the impacts of tourism, particularly during the peak tourist season from June to July and from December to January. Therefore, this study aims to measure residents' attitudes toward tourism development. Specifically, the sustainable tourism scale measurement developed by Choi and Sirakaya (2005) is employed. This scale has been widely used by other scholars.

\section{Sustainable Tourism as a Conceptual Framework}

This study employs sustainable tourism development as a conceptual framework. Tourism development should be based on the sustainable development concept. As emphasized by the World Commission on Environment and Development (WCED), sustainable development is defined as a process of change, which is all in harmony, and improves future potential to meet human needs and aspirations (WCED, 1987). Tourism development should make plans to avoid mass tourism and be focused on alternative tourism to achieve a balance between providing the needs of the local people and the tourists and encouraging responsible behaviors of visitors (cf. McIntyre, 1993; Choi \& Sirakaya, 2005). This notion suggests that tourism development emphasizes environmentally sound policies in tourism development management, economic and social aspects, and policy impacts. The knowledge of, opinion on, and application of power, resources, and rules must exist to develop sustainable tourism management policies, in cooperation with different stakeholders that should be included. According to the World Tourism Organization (WTO), tourism development should be defined as an effort to develop the needs of tourists and the host through an effort to protect and enhance opportunities for a good future. Stakeholders must be managed in such a way that everything is in balance, particularly with regard to economic and social aspects while maintaining cultural values and life support systems (McIntyre et al., 1993). The WTO definition requires at least four key elements in tourism development: ecological, cultural, social, and economic elements.

The ecological aspects of tourism primarily deal with a carrying capacity: the need to limit the number of visitors to minimize the environmental impact of tourism activities. Tourism should also limit environmental changes in such a way that it leads to destruction (Mowforth \& Munt, 2003, p. 106). Mowforth and Munt suggested that carrying capacities in tourism destinations are necessary to assess the environmental impact of tourism and to ensure sustainability. Furthermore, they calculated the capacities of the seven main tourist destinations in Costa Rica on the basis of the notion of sustainability aspects. Such a notion is beyond the current interpretation of many users of the term.

Table 2. Population of Yogyakarta and DIY and Visiting Tourists 2015-2018

\begin{tabular}{lllll}
\hline & \multicolumn{1}{c}{2015} & \multicolumn{1}{c}{2016} & \multicolumn{1}{c}{2017} \\
\hline Population of DIY Province & $3,679,176$ & $3,720,912$ & $3,656,108$ & $3,656,108$ \\
Population of Yogyakarta & 412,704 & 417,744 & 414,055 & 414,055 \\
International Tourists & 308,485 & 355,313 & 397,951 & 416,327 \\
Domestic Tourists & $3,813,720$ & $4,194,261$ & $4,831,347$ & $5,272,719$ \\
\hline
\end{tabular}

Source: Statistik Kepariwisataan 2019, Dinas Pariwisata DIY

\footnotetext{
${ }^{1}$ This study distinguishes between Yogyakarta City and Yogyakarta Province. As a province, Yogyakarta has five districts, namely, Sleman, Gunung Kidul, Kulon Progo, Bantul, and Yogyakarta City. We refer Yogyakarta Province to DIY Province (Daerah Istimewa Yogyakarta/Special Region of Yogyakarta). Meanwhile, we use the term "Yogyakarta" to refer to Yogyakarta City, which is the focus of this study.
} 
Societies may continue functioning in social harmony. However, the relationships within these societies, the interactions among the people, and customs are all subject to modify along with the introduction of visitors to different habits and styles (Mowforth \& Munt, 2003, p. 106). In general, the impacts of cultural aspects are easily observed over the long term and are thus difficult to measure although the cultural changes experienced by many local communities are well documented, especially but not exclusively by anthropologists (i.e., the cultural ill-effects of tourism, namely, cultural commodification).

Social aspects refer to the ability of community members, whether local or national, to absorb changes for short or long periods and to continue functioning. Communities can function with or without social disharmony. Societies can adapt functions and relationships, so that disharmony can be diminished. One negative tourism impact that has been investigated by previous studies is the opening of previously non-existent social divisions (cf. Mowforth \& Munt, 2003, p. 108).

One economic aspect is the level of economic benefit from a tourism activity. This gain can sufficiently cover the cost of any special measures taken to cater to tourists and to mitigate the effect of tourists' presence, or to offer an income compensating the inconvenience suffered by the local community visited-without violating any of the other conditions-or both. The economic multiplier effect should be strengthened, whereas economic leakage must be minimized, and most economic benefits should go to the local people (Gkoumas, 2019).

\section{The Methods}

\section{Re-evaluation of SUS-TAS Scale}

In this study, Yogyakarta residents' attitudes toward tourism development were assessed by relying on a sustainable tourism development scale developed by Choi and Sirakaya (2005). This scale was developed using extensive quantitative data, was re-validated by $\mathrm{Yu}$ et al. (2011), supports a seven-dimension SUS-TAS, and has internal consistency. This scale originally consisted of 44 items and has dimensional distinctiveness and stability, internal consistency, content validity, and convergent validity. In this study, the source of information on the SUSTAS scale was written in the Indonesian language. Such information was translated into English by the author.

\section{Sampling Technique}

Purposive random sampling was conducted by research assistants to collect data. Three areas in Yogyakarta were selected, and these areas are regarded as main tourist destinations, namely, Malioboro Street, Kraton, and Prawirotaman. The potential participants were asked whether they were interested in filling out a questionnaire concerning their perceptions toward tourism development. Those who agreed to participate in the survey completed the self-administered questionnaire in the presence of research assistants. The respondents involved in this survey were mainly people who had lived in Yogyakarta for at least one year, particularly in the three aforementioned tourism areas, indicated in their identity card (KTP). A total of 1,687 respondents agreed, representing an equal gender distribution.
Research Analysis

Confirmatory factor analysis (CFA) was conducted with an Oblimin rotation on the collected data to determine the scale dimensions. Yu et al. (2011) argued that the advantage of CFA is it allows for testing a hypothesis with regard to a certain model and an effective method to examine certain construct validity. To assess whether a particular data set is suitable for factor analysis, the strength of the relationship among the items was investigated. Items with factor loadings lower than 0.5 or cross-loaded on more than one factor were eliminated. In addition, the internal reliability of each factor was measured using Cronbach's alpha. According to Hall et al. (2006), if the reliability scores are higher than 0.7 , then the variables exhibit moderate correlation with their factor grouping and can be regarded as internally consistent and stable.

Descriptive analysis was also conducted to measure the residents' level of agreement toward different variables of sustainable tourism. The result was related to Doxey irritation index to understand the stage of tourism development in Yogyakarta.

\section{Results and Discussion}

This section discusses the empirical findings. The background characteristics of the respondents are first introduced, followed by residents' perceptions toward tourism development and their agreement on a tourism development concept.

\section{Residents' Personal Characteristics}

Table 3 shows that the gender distribution of the sample is nearly equal, $52.7 \%$ male and $47.3 \%$ female. Most participants are below 40 years old $(70.3 \%)$, which is considered a productive age. Most participants are also educated people, $36.6 \%$ of whom have university degrees, whereas $50.7 \%$ have finished senior high school; only $12.7 \%$ did not finish senior high school. With regard to employment, most respondents run private businesses, whereas $25.4 \%$ are university students. The monthly salaries of the respondents is lower than the national averages for particular employment categories. Approximately $85.4 \%$ receive less than USD 250 per month. The businesses ran by certain respondents are assumed to be small-scale. Approximately $63.9 \%$ report that they have been living in Yogyakarta for more than ten years. Only 3.3\% of them have been living in the region for less than one year. This variable is important for the validity of the findings because it indicates how well the respondents know about the situation in Yogyakarta. Their attitudes toward tourism development reflect their long-term experiences of living in Yogyakarta.

\section{Residents' Attitudes toward Sustainable Tourism Development}

Table 4 shows that this study is consistent with the sevendimension scale of residents' attitudes toward sustainable tourism developed by Choi and Sirakaya (2005) and Ci (2011), with the explained variance of $55.62 \%$. The scale consists of perceived social cost ( $\alpha .941)$, long-term planning (a.907), perceived economic benefit (a.889), maximized community participation (a.844), ensured visitor satisfaction (a.819), environmental sustainability (a.741), and community-centered economy (a.798). Perceived social cost 
Table 3. Descriptive Summary of Participants

\begin{tabular}{|c|c|c|c|}
\hline Variable & & Frequency & Percentage (\%) \\
\hline \multicolumn{4}{|c|}{ Age $(N=1,687)$} \\
\hline & $17-24$ & 670 & 39.7 \\
\hline & $25-39$ & 517 & 30.6 \\
\hline & $40-55$ & 387 & 22.9 \\
\hline & $>56$ & 113 & 6.7 \\
\hline \multicolumn{4}{|c|}{ Gender $(N=1,687)$} \\
\hline & Male & 889 & 52.7 \\
\hline & Female & 798 & 47.3 \\
\hline \multicolumn{4}{|c|}{ Education $(N=1,686)$} \\
\hline & Did not finish elementary school & 20 & 1.2 \\
\hline & Elementary school & 42 & 2.5 \\
\hline & Junior high school & 151 & 9.0 \\
\hline & Senior high school & 856 & 50.7 \\
\hline & University & 617 & 36.6 \\
\hline \multicolumn{4}{|c|}{ Employment $(N=1,679)$} \\
\hline & Police/Army & 24 & 1.4 \\
\hline & Private businessman & 878 & 52 \\
\hline & Government employee & 64 & 4.1 \\
\hline & Housewife & 146 & 8.7 \\
\hline & University student & 428 & 25.4 \\
\hline & Others & 86 & 5.1 \\
\hline \multicolumn{4}{|c|}{ Monthly salary $(N=1,668)$} \\
\hline & 0=USD 75 & 576 & 34.1 \\
\hline & USD 76-150 & 562 & 33.7 \\
\hline & USD 151-250 & 294 & 17.6 \\
\hline & USD $251-350$ & 104 & 7.9 \\
\hline & >USD 351 & 44 & 6.2 \\
\hline \multicolumn{4}{|c|}{ Length of stay $(N=1,683)$} \\
\hline & $<1$ year & 56 & 3.3 \\
\hline & $1-3$ years & 206 & 12.2 \\
\hline & $4-6$ years & 199 & 11.8 \\
\hline & $7-9$ years & 144 & 8.5 \\
\hline & $10-15$ years & 185 & 11 \\
\hline & $<16$ years & 893 & 52.9 \\
\hline
\end{tabular}

and long-term planning are the variables with the strongest internal consistency, whereas environmental sustainability and community-centered economy have the weakest internal consistency, although they are considerably acceptable.

This research also finds that the measurement of perceived social cost confirms the scale proposed by Choi and Sirakaya (2005), consisting of two aspects, namely, feeling irritated and loss of quality of life. The respondents were asked about the negative social impact of tourism on social feelings and quality of life. Feelings of being irritated and disrupted have the highest factor loadings. These variables indicate that when people of Yogyakarta perceive the social impact of tourism, they relate it to feelings of being irritated and disrupted. 
With regard to long-term planning, the finding confirms Choi and Sirikaya's (2005) scale. This research has also come up with one new item. The respondents believe that a longterm view is needed to reduce the negative impacts of tourism. For people of Yogyakarta, long-term planning is important not only for successful tourism management but also for well-coordinated planning that can reduce the negative impacts of tourism development.

In terms of perceived economic benefit, the finding supports the utility of the scale proposed by Choi and Sirikaya (2005). The respondents perceive that tourism development benefits other industries in their community. Tourism can diversify what is produced in local economies and can bring additional income to communities. The respondents perceive that another aspect should be included in perceived economic benefit, that is, investment. According to the respondents, tourism development should generate investment at the local and national levels.

The measurement of maximized community participation also supports the SUS-TAS scale. The respondents suggest that tourism development decisions must be made by involving all community members regardless of personal backgrounds. Community members should have an equal opportunity to be involved in tourism development management. Strzelecka et al. (2017) investigated that the full participation of community members in decision making is essential for successful tourism development. Two items came up in the discussion on community participation, namely, training and promoting tourism industries. According to the respondents, communities should receive training related to tourism activities. If tourism is considered a new industry for Indonesians, then the difficulties in providing welleducated and trained human resources are confirmed to exist. Another aspect that is considered important for the respondents is tourism promotion. Communities should be involved in promoting tourist destinations in their region.

An interesting finding emerges with regard to ensure visitor satisfaction. Only three items of the SUS-TAS scale appear in the measurement. According to the respondents, community attractiveness is a core element of ecological appeal for visitors, and the telecommunication industry must ensure that tourism experiences for visitors are positive. Tourism businesses must monitor visitor satisfaction. Moreover, the respondents feel disappointed if the services received by tourists are unsatisfactory. Four aspects should be developed to ensure visitor satisfaction, namely, accessibility, security, hygiene, and accommodation. According to the respondents, road maintenance is needed to facilitate the accessibility of attractions for tourists. Safety also affects the tourist satisfaction level. The respondents believe that tourist satisfaction can increase if public awareness of hygiene is evident. Tourist accommodation must also be further developed to ensure tourist satisfaction.

The measurement of environmental sustainability results in similar items to the SUS-TAS scale. According to the respondents, the community environment must always be protected. Tourism development should strengthen efforts for environmental conservation. The respondents perceive that tourism development must improve environmental quality for future generations. Regulatory environmental standards are needed to reduce the negative impacts of tourism development.
With regard to the community-centered economy, the respondents perceive that tourism businesses should hire at least one-half of their employees from the local community. The tourism industry must contribute to community improvement funds and should obtain at least one-half of their goods and services from the local community. Another important aspect for the respondents is the new item on the scale, that is, community members should be given additional opportunities to invest in tourism development.

\section{Level of Agreement with Sustainable Tourism}

The following discussion presents the level of agreement among the local residents with regard to the sustainable tourism development variables. Table 3 presents that environmental sustainability (mean $[\mathrm{m}]$ : 8.69; standard deviation [s.d.]: 1.12) has the highest level of agreement, according to Yogyakarta residents, followed by long-term planning (m: 8.53; s.d.: 1.14). Perceived economic benefit (m: 8.36; s.d.: 1.2) has a lower level of agreement than that of ensured visitor satisfaction (m: 8.49; s.d.: 1.1). Communitycentered economy (m: 8.11; s.d.: 1.25) has a higher level of agreement than that of community participation (m: 7.97; s.d.: 1.25). Interestingly, the finding shows that perceived social cost (m: 6.30; s.d.: 2.03) has the least level of agreement, which is slightly higher than that of maximized community participation.

Table 5 presents that, in general, people of Yogyakarta have positive attitudes toward tourism development. They agree that tourism development should protect environmental sustainability and be based on long-term planning. To ensure tourist satisfaction, destinations must be well managed, and tourism should bring about economic benefit to the local community. However, two aspects of sustainable tourism are considered problematic for people of Yogyakarta: community participation and social cost.

This study finds that community participation has the second-lowest level of agreement among the local residents. Community participation in tourism development has always been problematic (Lonardi et al., 2020). Local people likely support tourism development if it has positive impacts and offers financial benefits. In Yogyakarta, as in many other tourism destinations in Indonesia, financial benefits mostly go to tourism companies and people from outside the tourist destination areas. The Government Tourism Office in Yogyakarta has reported the decline of community participation in tourism. The data show that the number of travel agencies decreased from 275 in 2014 to 173 in 2016. Similarly, the number of people working as local tourist guides declined from 225 in 2014 to 202 in 2016 (Dinas Pariwisata DIY, 2016).

People also feel uncomfortable about the large scale development of the tourism industry in Yogyakarta. Ahnaf and Salim (2017) investigated that the development of hotels and shopping centers in the last 10 years has impacted clean water scarcity and increased criminality. Pizam et al. (2002) revealed that the main social problems related to tourism are the commodification of norms and values, criminality, and minimal access to public services due to tourism. These problems have emerged in Yogyakarta, especially to those living in the main tourism destinations, such as Prawirotaman, Kraton, and Malioboro. 
Table 4. Factor analysis (Paf, Oblimin rotation), commonality $\left(\mathrm{h}^{2}\right)$,

percentage of explained variance, and reliability (Cronbach's alpha) of sustainable tourism attitude

\begin{tabular}{llll}
\hline Factor & Factor loading Reliability coefficient ${ }^{2}$ \\
\hline
\end{tabular}

Perceived Social Cost

.94

(Excellent)

I often feel irritated due to tourism in my community.

.86

My quality of life has deteriorated due to tourism.

Long-term Planning

I believe that successful tourism management requires advanced planning.

I believe that we must have a long-term view when planning for tourism development.

I believe tourism development needs well-coordinated planning.

The tourism industry must plan for the future.

Tourism development plans should be continuously improved.

When planning for tourism, we cannot be short-sighted.

I think residents must be encouraged to assume leadership roles in tourism planning committees.

\section{Perceived Economic Benefit}

Tourism benefits other industries in communities.

Tourism diversifies local economies.

I like tourism because it brings new income to communities.

Tourism generates local investments.

I believe tourism is good for local community economies.

I believe tourism is a strong economic contributor to communities.

Tourism creates new markets for our local products.

Tourism generates substantial tax revenues for local governments.

\section{Maximized Community Participation}

Tourism decisions must be made by everyone in my community regardless of background.

It is okay if tourism development decisions do not involve everyone in communities.

Community residents should have an opportunity to be involved in tourism development management.

Full participation of everyone in communities in tourism-related decisions is a must for successful tourism development.

Communities should receive training related to tourism activities.
.84

.83

.79

.79

.77

.71

.91

(Excellent)

.89

(Good) 
Tourism decisions must be made by everyone in communities regardless of background.

$$
\text { Ensured Visitor Satisfaction }
$$

I feel disappointed if the services received by tourists are unsatisfactory.

Road maintenance should be done to facilitate accessibility for tourists.

Good security affects tourist satisfaction level.

Community attractiveness is a core element of ecological appeal for visitors.

Tourism industry must ensure good quality tourism experiences for visitors.

Tourist satisfaction can increase if public awareness of hygiene is evident.

Tourist accommodation must be developed to ensure tourist satisfaction.

Tourism businesses must monitor visitor satisfaction.

\section{Community-centered Economy}

I think tourism businesses should hire at least one-half of their employees from within the community.

Tourism industry must contribute to community improvement funds. Community residents should be given additional opportunities to invest in tourism development.

The tourism industry should obtain at least one-half of its goods and services from within the community.

$$
\text { Environmental Sustainability }
$$

Community environment must be protected now and in the future.

Tourism development should strengthen efforts for environmental conservation.

I believe tourism must improve the environment for future generations.

Each item has a 10-point Likert response set: strongly disagree to strongly disagree.

Total explained variance: $55.616 \%$

Table 5. Level of Agreement with Sustainable Tourism

\begin{tabular}{lcccc}
\hline \multicolumn{1}{c}{ Factor } & $\begin{array}{c}\text { Number of } \\
\text { items }\end{array}$ & $\mathrm{M}$ & S.D. & $N$ \\
\hline Environmental Sustainability & 5 & 8.69 & 1.12 & 1,687 \\
Long-term Planning & 7 & 8.53 & 1.14 & 1,687 \\
Ensured Visitor Satisfaction & 8 & 8.49 & 1.07 & 1,687 \\
Perceived Economic Benefit & 8 & 8.36 & 1.15 & 1,687 \\
Community-centered Economy & 4 & 8.11 & 1.25 & 1,687 \\
Maximized Community Participation & 8 & 7.97 & 1.25 & 1,687 \\
Perceived Social Cost & 7 & $6.30^{*}$ & 2.03 & 1,687 \\
\hline
\end{tabular}

Each item has a 10-point Likert response set: strongly disagree to strongly agree.

${ }^{*}$ Mean score after rotation 
This study provides support for Doxey's (1975) tourism irritation index. Accordingly, this index is developed to understand the irritation and destination response levels of people to tourism development. The index has four stages and is based on the understanding of local residents' irritation toward tourists and tourism development. Doxey (1975) confirmed that these stages are mainly the consequences of tourism development in terms of its varying social, economic, and environmental impacts on destinations (Higgins-Desbiolles, 2018; Poudel, 2016). This model indicates that tourism development tends to have a negative sociocultural tourism impact that can lead to irritation in local communities. The four stages of the Doxey index consists of euphoria, apathy, irritation, and antagonism, all of which explain the deteriorating response levels of local residents to tourism development. According to Fridgen (1991), although the index has been considered one of the most important models to describe residents' attitudes toward tourism development, the index also has a limitation. Studies have confirmed that this concept must be empirically-based and should consider the uniqueness of every locality. Brida et al. (2011) argued that the model assumes a degree of homogeneity and a positive linear relationship. The model also seems to ignore complexities within host communities and the multidimensionality of tourism impacts. Nevertheless, the model provides a useful framework to understand the changes in residents' attitudes and destinations' developmental stages; but its application should be empirically-based (Nunkoo, 2017).

By using the Doxey irritation index, the people of Yogyakarta are argued to have experienced irritation. Doxey (1975) defined the irritation level as when people begin to show misgivings toward the tourism industry due to increasing numbers of external investments and infrastructures. Vargas-Sánchez et al. (2011) indicated that the tourism development level perceived by residents has a negative correlation with their attitudes toward further tourism development. Coelho and Butler (2012) argued that resident population is an essential component in analyzing the irritation index, confirming that the number of tourists visiting Yogyakarta in the last three years is higher than the total population of Yogyakarta itself, and even higher than the population of DIY. Similarly, as reported by the chairman of the Indonesian Hotel and Restaurant Association of Yogyakarta, DIY Province has 166 star hotels and approximately 1,030 non-star hotels as of $2018,60 \%$ of which are located in Yogyakarta ${ }^{3}$.

Furthermore, Beeton (2006) indicated that the irritation index model could strengthen Butler's tourism area life cycle model, where the exploratory phase correlates with Doxey's euphoria stage, and it moves up along the line toward the antagonism level when the carrying capacity of a destination is exceeded. Tourism in Yogyakarta can also be described at a consolidation level on the basis of Butler's (1980) model. At this level, people may grow tyred of the development and increasing number of tourists.

Based on the dimensions within the social cost variable in the survey, tourism has rapidly grown that people feel irritated with the tourism industry. They believe that tourism has disrupted their lives, and the quality of their lives has been deteriorated by tourism. For many people of Yogyakarta, tourism has brought about traffic and overused recreational resources. A similar case is observed in several tourist destinations where tourism has rapidly developed, and unexpected negative impacts have occurred (Ward et al., 2016; Kim \& Ritchie, 2014; Knobloch; 2017).

\section{Conclusion}

Several research projects have shown the significant influence of residents' attitudes to tourism development. Stakeholders thus often refer to their tourism policies to research organizations to further understand people's attitudes. This study provides support for the SUS-TAS scale constructed by Choi and Sirikaya (2005). In the context of tourism development in Indonesia, particularly in Yogyakarta, several new items have appeared on the scale that strengthen the previously validated seven dimensions in the SUS-TAS scale.

Based on the Doxey irritation index analysis, tourism in Yogyakarta is considered to be at the stage of irritation, where people become uninterested in participating in the tourism industry and feel irritated by tourism development. These findings should be considered by stakeholders in developing tourism in Yogyakarta. The decreasing number of local residents participating in the tourism industry and social problems resulting from tourism should be carefully considered. Stakeholders should pay attention to the involvement of local residents and their quality of life.

However, note that the generalization of this research must be taken with caution. Although the data collected from certain respondents are abundant, as indicated by the number of respondents involved, the study is mainly based on specific quantitative data. Therefore, future research should collect additional data that can be quantitatively and qualitatively analyzed to complement the present findings. Another limitation is related to the scope. The choice of location in this study is only based on one tourist destination. Conducting comparative studies involving other tourist destinations and countries with similar cultural structures (i.e., Southeast Asian countries) can be a future research agenda. Such studies can provide a comprehensive picture of residents' attitudes toward tourism development at the national and international levels and in a regional context.

\section{Acknowledgment}

This research is supported by the Faculty of Cultural Science, Universitas Gadjah Mada. My sincere thanks go to anonymous reviewers who provided me with thorough comments.

\section{References}

Agonos, M.J.M., Bade, M.P.B., Marielle J.C., and Mercene, J.V. (2015). Family leisure affair: A qualitative study on negotiating leisure in families with OFW parent. SEARCH: The Journal of the South East Asia Research Centre for Communications and Humanities, 7(2), 83-105.

Ahnaf, I., and Salim, H. (2017). Krisis Keistmewaan Kekerasan terhadap Minoritas di Yogyakarta. Yogyakarta: CRCS.

\footnotetext{
${ }^{3}$ Retrieved from: http://www.beritasatu.com/satu/486015-okupansi-hotel-di-yogyakarta-capai-100-persen.html
} 
Aitchison, C., and Evans, T. (2001). The cultural industries and a model of sustainable regeneration: Manufacturing "pop" in the Rhondda Valleys of south Wales. Managing Leisure, 8 (3), 133-144. https:// doi.org/10.1080/1360671032000123663.

Ap, J., and Crompton, J.L. (1998). Developing and testing a tourism impact scale. Journal of Travel Research, 37(2), 120-30. https://doi.org/10.1177/004728759803700203.

Bankowski, Z., MacCormick, N., Summers, R.S., and Wroblewski, J. (1991). On method and methodology, in Neil MacCormick, R.S. Summers (eds.). Interpreting statutes: A comparative study. Dartmouth Press, pp. 9-28.

Berger, G. (2003). Reflections on governance: Power relations and policy making in regional sustainable development. Journal of Environmental Policy \& Planning, 5(3), 219-234. https:// doi.org/10.1080/1523908032000154160.

Brayley, R., Var, T., and Sheldon, P. (1990). Perceived influence of tourism on social issues. Annals of Tourism Research, 17 (2), 285-289. https://doi.org/10.1016/0160-7383(90)90089A.

Brida, J.G., Osti, L., Faccioli, M. (2011). Residents' perception and attitudes towards tourism impacts: A case study of the small rural community of Folgaria (Trentino - Italy). Benchmarking: An International Journal, 18(3), 359-385. https://doi.org/10.1108/14635771111137769

Brown, D.O. (1998). In search of an appropriate form of tourism for Africa: Lessons from the past and suggestions for the future. Tourism Management, 19(3), 237-245. https:// doi.org/10.1016/S0261-5177(98)00016-8.

Brunt, P., and Courtney, P. (1999). Host perceptions of sociocultural impacts. Annals of Tourism Research, 26(3), 493-515. https://doi.org/10.1016/S0160-7383(99)00003-1.

Butler, R.W. (1980). The Concept of a tourist area cycle of evolution: Implications for management of resources. Canadian Geographer, 24(1), 5-12. https://doi.org/10.1111/ j.1541-0064.1980.tb00970.x.

Choi, H.C., \& Sirakaya, E. (2005). Measuring Residents' Attitude toward Sustainable Tourism: Development of Sustainable Tourism Attitude Scale. Journal of Travel Research, 43, 380394. https://doi.org/10.1177/0047287505274651

Dinas Pariwisata Daerah Istimewa Yogyakarta (2016). Statistik Kepariwisataan 2016. Retrieved from: https:// visitingjogja.com/downloads/Buku\%20Statistik\% 20Kepariwisataan\%20DIY\%202016.pdf.

Disdikpora DIY (2017). Aplikasi Data DIY. Yogyakarta: Disdikpora DIY. Retrieved from http://pendidikan-diy.go.id/dinas_v4/? view=data-pendidikan.

Dobinson, I., and Johns, F. (2007). Qualitative legal research, in McConville, in Mike and Wing Hong Chui (eds.). Research methods for law. Edinburgh University Press, pp. 16-45.

Doxey, G. (1975). A causation theory of visitor-resident irritants: Methodology and research inferences. The Impact of Tourism. In the Sixth Annual Conference Proceedings, pp.195-198. San Diego: The Travel Research Association.

Duffield, B.S., and Long, J. (1981). Tourism in the highlands and islands of Scotland: Rewards and conflicts. Annals of Tourism Research, 8(3), 403-31. https:// doi.org/10.1016/0160-7383(81)90006-2.

Fridgen, J. (1991). Dimension of Tourism. Lansing: Educational Institute of the American Hotel and Lodging Association.

Hateftabar, F., and Chapuis, J.M. (2020). How resident perception of economic crisis influences their perception of tourism. Journal of Hospitality and Tourism Management, 43, 157168. https://doi.org/10.1016/j.jhtm.2020.02.009.

Gkoumas, A. (2019). Evaluating a standard for sustainable tourism through the lenses of local industry. Heliyon, 5(11), 1-12. https://doi.org/10.1016/j.heliyon.2019.e02707.

Higgins-Desbiolles, F. (2018). Sustainable tourism: Sustaining tourism or something more?. Tourism Management Perspectives, 25, 157-160. https://doi.org/10.1016/ j.tmp.2017.11.017.

Hsu, C.-Y., Chen, M., Nyaupane, G.P., and Lin, S.-H. (2020). Measuring sustainable tourism attitude scale (SUS-TAS) in an Eastern island context, Tourism Management Perspectives, 33, 1-10. https://doi.org/10.1016/ j.tmp.2019.100617.

Inskeep, E. (1991). Tourism Planning-An Integrated and Sustainable Development Approach. New York: Van Nostrand Reinhold.

Jooa, D., Heetae C., K.M. Woosnamc (2019). Exploring tourists' perceptions of tourism impacts. Tourism Management Perspectives, 31, 231-235

Kim, J.-H., \& Ritchie, J. R. B. (2014). Cross-cultural validation of a memorable tourism experience scale (MTES). Journal of Travel Research, 53(3), 323-335. http://doi.org/ $10.1177 / 0047287513496468$

Knobloch, U., Robertson, K., \& Aitken, R. (2017). Experience, Emotion, and Eudaimonia: A Consideration of Tourist Experiences and Well-being. Journal of Travel Research, 56 (5), 651-662. https://doi.org/10.1177/0047287516650937

Latimer, H. (1985). Developing island economies-tourism versus agriculture. Tourism Management, 6(1), 32-42. https:// doi.org/10.1016/0261-5177(85)90053-6.

Lonardi, S., Martini, U., \& Hull, J.S. (2020-In press). Minority languages as sustainable tourism resources: From Indigenous groups in British Columbia (Canada) to Cimbrian people in Giazza (Italy). Annals of Tourism Research, 136(3). https://doi.org/10.1016/ j.annals.2020.102859.

MacCormick, N., and Summers R.S. (eds.) (1991). Interpreting statutes: A comparative study. Dartmouth Press.

Mansfeld, Y., and Winckler, O. (2008). The role of the tourism industry in transforming a rentier to a long-term viable economy: The case of Bahrain. Current Issues in Tourism, 11(3), 237-267. https:// doi.org/10.1080/13683500802140307.

Maccarrone-Eaglen, A. (2009). An analysis of culture as a tourism commodity. Tourism Culture \& Communication 9(3), 151163. https://doi.org/10.3727/109830409X12596186103879.

McCreedy, C.C., O'Leary Joseph, T., and Fesenmaier, D. (1992). Family Structure and Its Relationship to Travel. Retrieved from https://www.nrs.fs.fed.us/pubs/gtr/gtr_ne160/ gtr_ne160_177.pdf.

McIntyre, G., Hetherington, A., Inskeep, E., and World Tourism Organization (1993). Sustainable Tourism Development: Guide for Local Planners. Madrid: A Tourism and the Environment Publication.

Mok, C., Slater, B., and Cheung, V. (1991). Resident's attitudes towards tourism in Hong Kong. Journal of Hospitality Management, 10(3), 289-293. https://doi.org/10.1016/02784319(91)90061-L.

Nunkoo, R. (2017). Governance and sustainable tourism: What is the role of trust, power and social capital? Journal of Destination Marketing and Management, 6(4), 277-285. https://doi.org/10.1016/j.jdmm.2017.10.003.

Pennington-Gray, L., Reisinger, Y., Kim, J.E., and Thapa, B. (2005). Do US tour operators' brochures educate the tourist on culturally responsible behaviours? A case study of Kenya. Journal of Vacation Marketing, 11(3), 265-84. https:// doi.org/10.1177/1356766705055719.

Pizam, A., Fleischer, A., and Mansfeld, Y. (2002). Tourism and social change: The case of Israeli ecotourists visiting Jordan. Journal of Travel Research, 41(2), 177-184. https:// doi.org/10.1177/004728702237423.

Poudel, S., Nyaupane, G.P., and Budruk, M. (2016). Stakeholders' perspectives of sustainable tourism development: A new approach to measuring outcomes. Journal of Travel Research, 55(4), 465-480. https:// doi.org/10.1177/0047287514563166.

Rasoolimanesh, S.M., Roldán, J.L., Jaafar, M., and Ramayah, T. 
(2017). Factors influencing residents' perceptions towards tourism development: Differences across rural and urban world heritage sites. Journal of Travel Research, 56(6), 760775. https://doi.org/10.1177/0047287516662354.

Shepherd, R. (2002). Commodification, culture and tourism. Tourist Studies, 2(2), 183-201. https:// doi.org/10.1177/146879702761936653.

Simpson, M.C. (2008). Community benefit tourism initiatives: A conceptual oxymoron?. Tourism Management, 29(1), 1-18. https://doi.org/10.1016/j.tourman.2007.06.005.

Sterkens, C., and Yusuf, M. (2015). Preferences for religious education and inter-group attitudes among Indonesian students. Journal of Empirical Theology, 28(1), 49-89. https://doi.org/10.1163/15709256-12341324.

Strzelecka, M.B. Boley, B.B., and Strzelecka, C. (2017). Empowerment and resident support for tourism in rural Central and Eastern Europe (CEE): The case of Pomerania, Poland. Journal of Sustainable Tourism, 25(4), 554-572. https://doi.org/ 10.1080/09669582.2016.1224891.

WCED (1987). Our Common Future. Oxford: Oxford University Press.

Ward, J.D., Sutton, P.C., Werner, A.D., Costanza, R., Mohr, S.H., and Simmons, C.T. (2016). Is decoupling GDP growth from environmental impact possible?. PLoS One, 11(10), e0164733. http://dx.doi.org/10.1371/journal.pone.0164733.

Yusuf, M. (2013). When cultural ritual meets religion: The Muludan tradition in the Kanoman Sultanate, Cirebon, West Java. Al-Albab, 2, 27-52. https://doi.org/ 10.24260/ alalbab.v2i1.20.

Yusuf, M., Samsura, D.A.A., and Yuwono, P.S.H. (2018). Toward a framework for an undergraduate academic tourism curriculum in Indonesian Universities: Some perspectives from stakeholders. Journal of Hospitality, Leisure, Sport \& Tourism Education, 22, 63-74. https://doi.org/10.1016/ j.jhlste.2018.02.003.

Zuo, B., Gursoy, D., and Wall, G. (2017). Residents' support for red tourism in China: The moderating effect of central government. Annals of Tourism Research, 64, 51-63. https://doi.org/10.1016/j.annals.2017.03.001. 